\title{
Rearing in captivity affects spermatogenesis and sperm quality in greater amberjack, Seriola dumerili (Risso, 1810) ${ }^{1}$
}

\author{
R. Zupa,* C. Fauvel, $\uparrow$ C. C. Mylonas,, C. Pousis,* N. Santamaria,* \\ M. Papadaki, $\$$ I. Fakriadis, $\$ \S$ V. Cicirelli,* S. Mangano,\# L. Passantino,* \\ G. M. Lacalandra,* and Aldo Corriero*2
}

\begin{abstract}
*Department of Emergency and Organ Transplantation, Section of Veterinary Clinics and Animal Production, University of Bari Aldo Moro, Valenzano 70010 (Bari), Italy; †UMR MARBEC, IRD-UM2-CNRS-IFREMER, Station Ifremer, Palavas 34250, France; $\ddagger$ Institute of Marine Biology, Biotechnology and Aquaculture, Hellenic Center for Marine Research, Heraklion 71003, Crete, Greece; §Department of Biology, University of Crete, Heraklion 71003, Crete, Greece; and \#Institute for Marine Coastal Environment, National Research Council, Capo Granitola 91021 (TP), Italy
\end{abstract}

\begin{abstract}
The greater amberjack, Seriola dumerili (Risso, 1810), is a promising candidate for the diversification of European aquaculture production, but inconsistent reproduction in captivity prevents commercial production. Recent studies showed that greater amberjack confined in sea cages exhibited scarce gonad development and early interruption of gametogenic activity during the reproductive season. The aim of the present study was to improve our understanding of the observed impairment of spermatogenesis. Adult wild and captive-reared males were sampled during 3 different phases of the reproductive cycle: early gametogenesis (EARLY; late April to early May), advanced gametogenesis (ADVANCED; late May to early June), and spawning (SPAWNING; late June to July). Spermatogonial stem cells and proliferating germ cells were identified through the immunohistochemical localization of Pou5f1 and proliferating cell nuclear antigen, respectively. Apoptotic germ cells were identified throughout the terminal deoxynucleotidyl transferase-mediated 2'-deoxyuridine 5'-triphosphate nick end labeling
\end{abstract}

method. Sperm quality of captive-reared fish was evaluated using computer-assisted sperm analysis. Captive-reared males exhibited seminiferous lobules of a smaller diameter, a precocious and progressive decrease of spermatogonial mitosis, and a high level of apoptosis at the beginning of the reproductive season, concomitant with a many-fold higher $17 \beta$-estradiol plasma concentration. The motile spermatozoa percentage of captive greater amberjack was lower than in other teleosts, and a drastic decrease of spermatozoa motility duration, velocity, and ATP content occurred along the reproductive season. An abnormal increase of sperm concentration as well as an increase of dead spermatozoa occurred during the SPAWNING phase, probably because of lack of sperm hydration and ejaculation and consequent sperm ageing. The present study demonstrates the extreme susceptibility of greater amberjack to rearing stress and underscores the need for improvement of the rearing and handling procedures to ameliorate gametogenesis dysfunctions in commercial aquaculture production.

Key words: germ cell apoptosis, germ cell proliferation, greater amberjack, rearing in captivity, Seriola dumerili, sperm quality

(C) 2017 American Society of Animal Science. All rights reserved.

J. Anim. Sci. 2017.95 doi:10.2527/jas2017.1708

\footnotetext{
${ }^{1}$ This project has received funding from the European Union's Seventh Framework Programme for research, technological development and demonstration (KBBE-2013-07 single stage, GA 603121, DIVERSIFY). The identification and description of stem spermatogonia was performed thanks to a grant from the Apulian Region to R.Z. (Fondo di Sviluppo e Coesione 2007-2013 - APQ Ricerca Regione Puglia "Programma regionale a sostegno della specializzazione intelligente e della sostenibilità sociale ed ambientale-FutureInResearch). Thanks are due to Peppe, Giovanni
}

and Vincenzo Billeci, and all the crew of the purse seine fishing vessel Graziella for their hospitality on board and assistance during wild greater amberjack sampling. Special thanks are due to Mr Tasos Raftopoulos of Argosaronikos Fishfarms S.A. (Greece) for the hospitality in his farm and the maintenance and sampling of captive-reared greater amberjack broodstock.

${ }^{2}$ Corresponding author: aldo.corriero@uniba.it

Received May 9, 2017.

Accepted July 5, 2017. 


\section{INTRODUCTION}

The greater amberjack, Seriola dumerili (Risso, 1810), is a highly valuable teleost considered a promising aquaculture species. However, proper commercial aquaculture production of the species has not developed so far, mainly due to its unpredictable reproduction in captivity (Micale et al., 1999; Garcia et al., 2001; Kožul et al., 2001a; Mylonas et al., 2004), which prevented the development of hatchery production of juveniles and the conversion of the capturebased farming activity into a true aquaculture industry.

A renewed effort to develop a technology for aquaculture production of greater amberjack is currently in progress within the European Union project DIVERSIFY (http://www.diversifyfish.eu/; accessed 17 March 2017). A comparative study on the reproductive development in captive-reared greater amberjack (Zupa et al., 2017) demonstrated reduced testis development and an early cessation of spermatogenic activity; this gametogenesis impairment was associated with important changes in sex steroid plasma concentrations. Gametogenesis dysfunctions in fish reared in captivity involve inadequate pituitary gonadotropin synthesis and/or release (Zohar and Mylonas, 2001; Mylonas et al., 2010; Berkovich et al., 2013), which has been attributed to captivity-induced stress, lack of suitable environmental conditions (Mylonas et al., 2010), and/or nutritional deficiencies (Izquierdo et al., 2001). Spermatogenesis dysfunctions may result in a qualitative and quantitative decrease of sperm output (Rurangwa et al., 2004; Cabrita et al., 2009; Bobe and Labbé, 2010) and, therefore, in unsuccessful spawning and production of fertilized eggs.

The aim of the present study was 1) to compare male germ cell proliferation and apoptosis in wild and captive-reared greater amberjack sampled in different phases of the reproductive cycle and 2) to assess sperm quality of greater amberjack specimens reared in sea cages, in an effort to improve our understanding on the spermatogenesis impairment recently described in this species (Zupa et al., 2017).

\section{MATERIALS AND METHODS}

\section{Sample Collection}

This study did not fall within the obligations contained in the Italian decree number 26 of March 4, 2014, regarding the permission to carry out research studies on experimental animals (http://www.gazzettaufficiale.it/eli/id/2014/03/14/14G00036/sg; accessed 12 April 2017) and did not need approval from any ethics committee, because the fish came from a registered aquaculture facility and from commercial catches and the research did not involve any experiments on live animals. Captive-reared fish originally came from the fishery at $0+$ year of age and were then reared at a registered aquaculture facility for $3 \mathrm{yr}$, according to routine farming practices, before they were recruited for this study, sacrificed, and sampled. No specific permission was required for wild greater amberjack sampling because these fish were commercially caught from an authorized purse seine fishing vessel during routine fishing operations. Immediately after death, those fish whose size was beyond that of first maturity (Kožul et al., 2001b) were purchased and sampled on board. The greater amberjack is classified as "Least Concern" in the International Union for Conservation of Nature Red List of Threatened Species (SmithVaniz et al., 2015).

In the present study, the same male wild and captive-reared greater amberjack used in Zupa et al. (2017) were analyzed. A total of 14 wild and 12 captive-reared greater amberjack males were sampled in 3 different phases of the reproductive cycle that were determined according to the available literature (Mandich et al., 2004; Sley et al., 2014): early gametogenesis (EARLY; late April to early May), advanced gametogenesis (ADVANCED; late May to early June), and spawning (SPAWNING; late June to July). Wild fish were caught by a professional purse seine fishing vessel during 2 consecutive fishing seasons (2014-2015) around the Pelagic Islands (Sicily, Italy). Immediately after capture, fish were placed on ice and left to die before sampling. Captive-reared fish belonged to a broodstock captured in the area of Astakos (Ionian Sea) in 2011 and transferred into a sea cage of Argosaronikos Fish Farms SA (Salamina Island, Greece) in September 2013. Fish ( $n=28$ of an approximately $1: 1$ male:female ratio) were reared for $2 \mathrm{yr}$ according to standard farming practices and fed to apparent satiation with a commercial extruded broodstock diet (Vitalis Cal; Skretting SA, Stavanger, Norway) every other day. For each sampling, a portion of the whole population of the captive-reared fish (approximately 12 fish) were confined to one side of the cage and were herded into a rectangular polyvinyl chloride anesthesia "bag" (15 $\mathrm{m}^{3}$ volume) and then lightly anesthetized with $0.01 \mathrm{~mL} / \mathrm{L}$ clove oil. Then, one by one, individual breeders were gently directed into a polyvinyl chloride stretcher, brought on board a service vessel, and deeply anesthetized with 0.03 $\mathrm{mL} / \mathrm{L}$ clove oil for sex recognition by means of gonad cannulation. Subsequently, 10- to $20-\mathrm{mL}$ blood samples were taken from the caudal vasculature using a heparinized syringe and then transferred to $10-\mathrm{mL}$ tubes containing $200 \mathrm{IU}$ sodium heparin $/ \mathrm{mL}$ of blood. Then, fish were euthanized by decapitation, placed in 
Table 1. Biometric data, gonadosomatic index (GSI), and maturity state of wild and captive-reared greater amberjack males sampled during the reproductive season in the Mediterranean Sea ${ }^{1}$

\begin{tabular}{|c|c|c|c|c|c|c|}
\hline $\begin{array}{l}\text { Fish } \\
\text { state }\end{array}$ & $\begin{array}{l}\text { Sampling } \\
\text { date }\end{array}$ & $\begin{array}{c}\mathrm{FL}^{2} \\
\mathrm{~cm}\end{array}$ & $\begin{array}{c}\mathrm{BM},{ }^{3} \\
\mathrm{~kg}\end{array}$ & $\begin{array}{c}\mathrm{TM}^{4} \\
\mathrm{~g}\end{array}$ & $\begin{array}{c}\text { GSI, } \\
\%\end{array}$ & Reproductive state \\
\hline \multicolumn{7}{|c|}{ Early gametogenesis } \\
\hline \multirow[t]{5}{*}{ Wild } & \multirow{5}{*}{$\begin{array}{c}\text { May } 1, \\
2015\end{array}$} & 111 & 14 & 300 & 2.14 & \multirow{5}{*}{$\begin{array}{l}\text { All spermatogenic } \\
\text { stages; luminal } \\
\text { spermatozoa }\end{array}$} \\
\hline & & 112 & 20 & 450 & 2.25 & \\
\hline & & 112 & 15 & 300 & 2.00 & \\
\hline & & 113 & 19 & 400 & 2.10 & \\
\hline & & 117 & 19 & 550 & 2.89 & \\
\hline \multirow[t]{4}{*}{ Captive } & \multirow{4}{*}{$\begin{array}{l}\text { Apr. 24, } \\
2015\end{array}$} & 92 & 12 & 65 & 0.54 & \multirow{4}{*}{$\begin{array}{l}\text { All spermatogenic } \\
\text { stages; few luminal } \\
\text { spermatozoa }\end{array}$} \\
\hline & & 94 & 12 & 60 & 0.50 & \\
\hline & & 94 & 13 & 60 & 0.46 & \\
\hline & & 101 & 15 & 95 & 0.63 & \\
\hline \multicolumn{7}{|c|}{ Advanced gametogenesis } \\
\hline \multirow[t]{4}{*}{ Wild } & \multirow{4}{*}{$\begin{array}{c}\text { May } 31, \\
2014\end{array}$} & 99 & 14 & 1,150 & 8.21 & \multirow{4}{*}{$\begin{array}{l}\text { All spermatogenic } \\
\text { stages; plenty } \\
\text { of luminal } \\
\text { spermatozoa }\end{array}$} \\
\hline & & 102 & 13 & 650 & 5.00 & \\
\hline & & 115 & 19 & 2,200 & 11.57 & \\
\hline & & 124 & 22 & 1,900 & 8.63 & \\
\hline \multirow[t]{4}{*}{ Captive } & \multirow[t]{4}{*}{$\begin{array}{c}\text { June 4, } \\
2015\end{array}$} & 90 & 9 & 370 & 4.11 & \multirow{2}{*}{$\begin{array}{l}\text { Ended } \\
\text { spermatogenesis; } \\
\text { plenty of luminal } \\
\text { spermatozoa }\end{array}$} \\
\hline & & 97 & 14 & 295 & 2.10 & \\
\hline & & 98 & 13 & 600 & 4.61 & \multirow{2}{*}{$\begin{array}{l}\text { All spermatogenic } \\
\text { stages; plenty } \\
\text { of luminal } \\
\text { spermatozoa }\end{array}$} \\
\hline & & 103 & 15 & 690 & 4.60 & \\
\hline \multicolumn{7}{|l|}{ Spawning } \\
\hline \multirow[t]{5}{*}{ Wild } & \multirow{3}{*}{$\begin{array}{c}\text { June } 29, \\
2015\end{array}$} & 100 & 12 & 650 & 5.41 & \multirow{3}{*}{$\begin{array}{l}\text { All spermatogenic } \\
\text { stages; plenty } \\
\text { of luminal } \\
\text { spermatozoa }\end{array}$} \\
\hline & & 102 & 14 & 700 & 5.00 & \\
\hline & & 104 & 16 & 950 & 5.93 & \\
\hline & \multirow{2}{*}{$\begin{array}{c}\text { June } 30 \\
2014\end{array}$} & 99 & 11 & 577 & 5.24 & \multirow[b]{2}{*}{$\begin{array}{l}\text { Partially spent; } \\
\text { residual luminal } \\
\text { spermatozoa }\end{array}$} \\
\hline & & 100 & 11 & 400 & 3.63 & \\
\hline \multirow[t]{4}{*}{ Captive } & \multirow{4}{*}{$\begin{array}{c}\text { July 2, } \\
2015\end{array}$} & 91 & 10 & 70 & 0.70 & \multirow{4}{*}{$\begin{array}{l}\text { Ended } \\
\text { spermatogenesis; } \\
\text { small number } \\
\text { of luminal } \\
\text { spermatozoa }\end{array}$} \\
\hline & & 95 & 11 & 155 & 1.40 & \\
\hline & & 96 & 13 & 140 & 1.07 & \\
\hline & & 96 & 12 & 130 & 1.08 & \\
\hline
\end{tabular}

${ }^{1}$ Table modified from Zupa et al. (2017).

${ }^{2} \mathrm{FL}=$ fork length.

${ }^{3} \mathrm{BM}=$ body mass

${ }^{4} \mathrm{TM}=$ testis mass.

crushed ice, and transferred to the farm facility for the subsequent sample collection. The procedure was repeated until a total of 4 males (and 4 females that were not examined in the present study) were sampled.

Biometric data (fork length [nearest $\mathrm{cm}$ ], body mass [nearest kg], and testis mass [nearest $\mathrm{g}]$ ), gonadosomatic index (GSI $=100 \times$ testis mass/body mass), and reproductive state are reported in Table 1 (data already presented in Zupa et al., 2017). One-centimeter-thick cross-sections were taken from one of the testis of each fish and fixed in 10\% buffered formalin for further histological (germ cell type description), immunohistochemical (stem and proliferating germ cells), and apoptosis analysis. For the assessment of sperm quality, sperm samples were taken from all 12 captive-reared greater amberjack. After unsuccessful attempts to collect sperm by applying pressure on the fish's abdomen, samples of intratesticular semen were obtained by squeezing the dissected testes. Part of each sperm sample was left undiluted and part was diluted 1:3 (vol/vol) in modified Leibovitz medium according to Fauvel et al. (2012); all the samples were stored at $4^{\circ} \mathrm{C}$ until analysis, which took place within $30 \mathrm{~min}$.

\section{Histology, Immunohistochemistry, and Identification of Apoptotic Germ Cells}

Testis slices were dehydrated in ethanol, clarified in xylene, and embedded in paraffin wax. Fourmicrometer-thick sections were cut and stained with hematoxylin and eosin or processed for immunohistochemistry and for detection of apoptotic cells. The identification of spermatogonial stem cells was performed through the immunohistochemical identification of Pou5f1, a transcription factor involved in the maintenance and self-renewal of undifferentiated and pluripotent cells, which is considered a reliable molecular marker for spermatogonial stem cells in fish (Schulz et al., 2010; Lacerda et al., 2014). The identification of proliferating germ cells was performed through the immunohistochemical localization of the proliferating cell nuclear antigen (PCNA), a polymerase delta accessory protein that is synthesized in the late G1 and S phases of the cell cycle and is, therefore, used as a nuclear marker of proliferation.

The immunohistochemical detection of Pou $5 \mathrm{f} 1$ and PCNA was performed using the same protocol, with the exception of an antigen retrieval procedure that was applied to only Pou5f1 immunostaining. This procedure was performed by boiling testis sections in citrate buffer (0.01 M, pH 6.0; $4 \times 5$-min cycles) in a microwave oven on high power $(750 \mathrm{~W})$. Endogenous peroxidase was inhibited by treating sections for 10 min with $3 \% \mathrm{H}_{2} \mathrm{O}_{2}$ and then rinsing them with distilled water and PBS $(0.01$ $M, \mathrm{pH} 7.4$, containing $0.15 \mathrm{M} \mathrm{NaCl}$ ). Subsequently, sections were incubated for $30 \mathrm{~min}$ in normal horse serum (Vector Laboratories, Inc., Burlingame, CA) to block nonspecific binding sites for immunoglobulins and then incubated overnight in a moist chamber at $4^{\circ} \mathrm{C}$ with rabbit polyclonal antibodies raised against synthetic peptide of Pou5f1 (Abnova Corp., Taipei, Taiwan) and monoclonal antibodies to PCNA (Santa Cruz Biotechnology, Inc., Dallas, TX). Anti-Pou5f1 and anti-PCNA antibodies were diluted 1:500 and 1:100, respectively, 
in PBS containing 0.1\% BSA (Sigma-Aldrich S.r.l., Milan, Italy). After rinsing for $10 \mathrm{~min}$ in PBS, immunohistochemical visualization was obtained using the Vectastain Universal Elite Kit (Vector Laboratories, Inc.). This method uses the avidin-biotin-peroxidase complex procedure. Peroxidase activity was visualized by incubating for 10 min with a Vector DAB (3,3'-diaminobenzidine) Peroxidase Substrate Kit (Vector Laboratories, Inc.), which produces a brown precipitate. To confirm the specificity of the immunoreaction, a control-staining procedure was performed by replacing the primary antibody with normal horse serum and PBS.

The localization of apoptotic germ cells was performed using the terminal deoxynucleotidyl transferase-mediated 2'-deoxyuridine 5'-triphosphate nick end labeling (TUNEL) method with an in situ Cell Death Detection Kit, AP (Roche Diagnostics Deutschland $\mathrm{GmbH}$, Mannheim, Germany) that was used in accordance with the manufacturer's instructions. Prior to incubation with the reaction mixture, the sections, after their rehydration through graded ethanol solutions, were incubated in a permeabilization solution of $0.1 \%$ Triton X-100 (Sigma-Aldrich S.r.1.) in 0.1\% sodium citrate for $8 \mathrm{~min}$ at $37^{\circ} \mathrm{C}$. Terminal deoxynucleotidyl transferase was diluted 1:10 in TUNEL Dilution Buffer (Roche Diagnostics Deutschland GmbH). A readyto-use solution of nitro-blue tetrazolium chloride/5bromo-4-chloro-3'-indolyphosphate p-toluidine salt (Roche Diagnostics Deutschland $\mathrm{GmbH}$ ) served as a substrate for the signal conversion.

\section{Seminiferous Lobule Diameter and Quantification of Germ Cell Proliferation and Apoptosis}

At least 50 seminiferous lobules were randomly selected and measured from the sections used for germ cell proliferation and apoptosis analyses. The density of anti-PCNA-positive single A spermatogonia (number of cells $/ \mathrm{mm}^{2}$ germinal epithelium) and the density of anti-PCNA-positive spermatocysts (i.e., number of cysts containing type A and type B spermatogonia or primary spermatocytes $/ \mathrm{mm}^{2}$ germinal epithelium), as well as the surface occupied by TUNEL-positive apoptotic cells ( $\mu \mathrm{m}^{2} / \mathrm{mm}^{2}$ germinal epithelium), were measured on 5 randomly selected fields of each testicular section. All these parameters were measured from microphotographs taken with a digital camera (DFC 420; Leica Microsystems, Cambridge, UK) connected to a light microscope (DIAPLAN; Ernst Leitz GmbH, Wetzlar, Germany), using image analysis software (Leica Application Suite, version 3.3.0; Leica Microsystems).

\section{Sex Steroid Plasma Level Measurement}

Plasma was separated from the blood by centrifugation $(2,408 \times g$ for $5 \mathrm{~min}$ at room temperature $)$ and then was kept at $-80^{\circ} \mathrm{C}$ until assayed for sex steroid determination. For the quantification of 17 $\beta$-estradiol $\left(\mathbf{E}_{\mathbf{2}}\right)$, an ELISA kit was used (Cayman Chemical Company, Ann Arbor, MI). For the $\mathrm{E}_{2}$ extraction, $200 \mu \mathrm{L}$ of plasma was extracted twice with $2 \mathrm{~mL}$ diethyl ether. Extraction was done by vigorous vortexing (Vibramax 110; Heidolph Instruments GmbH \& Co.KG, Schwabach, Germany) for $3 \mathrm{~min}$. After vortexing, samples were frozen for 10 min at $-80^{\circ} \mathrm{C}$ and the supernatant organic phase was collected in new tubes and evaporated under a stream of nitrogen (Pierce Reacti-Vap III, Thermo Scientific, Rockford, IL. Samples were reconstituted in reaction buffer for running for the ELISA.

\section{Analysis of Sperm Quality}

The analyses of the captive-reared greater amberjack sperm quality were performed at the sampling site (Argosaronikos Fish Farms SA), using a microscope (Eclipse 50i; Nikon Instruments Europe BV, Amsterdam, The Netherlands) equipped with a video camera (Sony ExWaveHAD, Model No. SSC-DC58AP, Tokyo, Japan) recording 25 frames per second. To estimate spermatozoa (spz) concentration (spz/mL), sperm samples were diluted to $1: 500(\mathrm{vol} / \mathrm{vol})$ in tap water and placed on a cell counting chamber (Thoma; $0.1 \mathrm{~mm}$ depth; Precicolor, HBG, Giessen-Luetzellinden, Germany). Spermatozoa were allowed to settle on the counting chamber for $10 \mathrm{~min}$, and then pictures were taken with the microscope at 20x magnification, focused so as to get highly contrasted spermatozoa and a slightly apparent grid. The particles were then counted on a cropped part of each picture adjusted to a known number of squares using the free software ImageJ (National Institutes of Health, Bethesda, MD).

To assess motility, a $20-\mu \mathrm{L}$ sperm sample from each fish was initially diluted $(1: 10, \mathrm{vol} / \mathrm{vol})$ in modified Leibovitz medium and then activated by mixing with $1 \mathrm{~mL}$ seawater containing 2\% BSA, for a final dilution of 1:500 ( $\mathrm{vol} / \mathrm{vol})$; concomitantly, the 25-frames-persecond video record (avi format) was launched so as to record sperm activity from its beginning. Immediately after short mixing by a vigorous shake, $1 \mu \mathrm{L}$ of activated sperm was placed in a prefocused, $10-\mu \mathrm{m}-$ deep, dedicated cell (Leja Products B.V., Nieuw-Vennep, The Netherlands) on the microscope. The recording was stopped at the cessation of any progressive spermatozoa movement. The time between activation and first possible motility analysis was around $10 \mathrm{~s}$. For computer-assisted sperm analysis (CASA), the videos were subsequently transformed into sequences of 
frames using the free software Virtualdub (http:/www. virtualdub.org/; 20 April 2014); then, sequences of $2 \mathrm{~s}$ (e.g., 50 frames) were analyzed every $10 \mathrm{~s}$ using the plugin CASA developed by Wilson-Leedy and Ingermann (2007) for ImageJ software. Due to variations of motility recording quality at the different times of sampling, the image treatment settings were adjusted to each sampling time and each sample, whereas the parameters of CASA associated with motility evaluation were common for all analyses. The only motility features that showed variations among the 3 different phases of the reproductive cycle and were relevant were the motility (\% of motile spz) and the velocity on a smoothed trajectory called average path velocity (VAP; $\mu \mathrm{m} / \mathrm{s})$. Therefore, only these values are presented.

To determine spermatozoa ATP content, 1- and $10-\mu \mathrm{L}$ aliquots of each sperm sample were prepared according to Boryshpolets et al. (2009) and assessed using an ATPlite luminescence kit (PerkinElmer, Inc., Waltham, MA). The integrity of spermatozoa plasma membrane was tested using a LIVE/DEAD Sperm Viability Kit (Molecular Probes, Eugene, OR) after dilution to $1: 100$ (vol/vol) and prefixation for $4 \mathrm{~min}$ in $4 \%$ glutaraldehyde as described by Beirão et al. (2009). This procedure stains live, dying, and dead spermatozoa in fluorescent green, green + red, and red, respectively.

\section{Statistical Analysis}

Differences in GSI, mean diameter of seminiferous lobules, density of anti-PCNA-positive single A spermatogonia, density of anti-PCNA-positive spermatocysts (cysts containing type A and type B spermatogonia + cysts containing primary spermatocytes), surface occupied by apoptotic germ cells, and sex steroid concentrations were evaluated by a 2-tailed Student's $t$ test in the following groups: wild specimens sampled in consecutive phases of the reproductive cycle, captivereared specimens sampled in consecutive phases of the reproductive cycle, and wild vs. captive-reared specimens sampled in the same phase of the reproductive cycle. Prior to the Student's $t$ test, the raw data of GSI and apoptotic surfaces were arcsine transformed, as appropriate with proportions (Sokal and Rohlf, 1981).

Differences in the sperm quality indexes among sampling phases were assessed either by ANOVA (after angular transformation in the case of $\%$ of motile spermatozoa), or by nested design ANOVA (in the case of sperm velocity where individual spermatozoa performances were taken into account for each male at the different sampling periods). Means were compared using Duncan's new multiple range post hoc test. All the results are presented as means $\pm \mathrm{SE}$, and the statistical probability significance was established at the $P<0.05$ level.

\section{RESULTS}

\section{Changes in Gonadosomatic Index and Diameter of Seminiferous Lobules}

Both in wild and captive-reared fish, GSI and seminiferous lobule diameter significantly increased $(P<$ 0.05 ) from the EARLY to ADVANCED periods and decreased thereafter (Table 2). Wild fish had higher GSI compared with captive-reared fish at all 3 phases $(P<0.05)$, and seminiferous lobules were significantly larger $(P<0.05)$ in wild than in captive-reared greater amberjack during the EARLY and SPAWNING phases.

\section{Histological and Immunohistochemical Analysis of the Testes}

In sections stained with hematoxylin and eosin, 2 types of single A spermatogonia were identified: a smaller cell type $(8.0 \pm 0.1 \mu \mathrm{m}$ diameter $)$, having a spherical nucleus, with heterochromatin dots and 2 nucleoli, surrounded by a thin acidophilic cytoplasm (Fig. 1a), and a larger cell type $(10.6 \pm 0.2 \mu \mathrm{m}$ diameter), showing a roundish/ovoidal nucleus with a prevalent euchromatic appearance and sparse heterochromatic patches, with a preeminent nucleolus and an acidophilic cytoplasm (Fig. 1a). The immunohistochemical staining with antibodies against the stemness marker Pou5f1 labeled single intralobular cells as well as sparse interlobular cells (Fig. 1b). Intralobular antiPou5f1-positive cells were more frequently observed beneath the tunica albuginea and, according to their size, they presumptively corresponded to the smaller type A single spermatogonia.

Spermatogonia contained in cysts also appeared as 2 different cell types: larger cells $(8.8 \pm 2.0 \mu \mathrm{m}$ mean diameter) with one or more nucleoli and a moderately acidophilic cytoplasm (presumptively type A spermatogonia; Fig. 1a) and smaller cells $(4.8 \pm 0.8$ $\mu \mathrm{m}$ mean diameter), showing a small heterochromatic nucleus and thin rim of a weakly acidophilic cytoplasm (Fig. 1a), making part of larger cysts (presumptively type B spermatogonia).

The appearance of primary $(4.4 \pm 0.9 \mu \mathrm{m})$ and secondary $(3.3 \pm 0.8 \mu \mathrm{m})$ spermatocytes differed according to the different phases of meiosis; metaphasic figures were often observed within spermatocyte I and spermatocyte II cysts (Fig. 1a). Spermatids had a mean diameter of $2.6 \pm 0.7 \mu \mathrm{m}$ and were characterized by a compact and strongly basophilic nucleus (Fig. 1a). Flagellated spermatozoa showed an oval head intensely stained with hematoxylin and were observed 
Table 2. Mean (SE) gonadosomatic index (GSI) and seminiferous lobule diameters of wild and captive-reared greater amberjack males sampled during the reproductive season in the Mediterranean Sea

\begin{tabular}{|c|c|c|c|}
\hline Fish state & Early gametogenesis & Advanced gametogenesis & Spawning \\
\hline \multicolumn{4}{|l|}{$\overline{\text { GSI, } \%}$} \\
\hline Wild & $2.3(0.2)^{\mathrm{a}}$ & $8.3(1.3)^{\mathrm{a}, \mathrm{z}}$ & $5.1(0.4)^{\mathrm{a}, \mathrm{z}}$ \\
\hline Captive & $0.5(0.1)^{\mathrm{b}}$ & $3.8(0.6)^{\mathrm{b}, \mathrm{z}}$ & $1.1(0.1)^{\mathrm{b}, \mathrm{z}}$ \\
\hline \multicolumn{4}{|c|}{ Seminiferous lobule diameter, $\mu \mathrm{m}$} \\
\hline Wild & $135.6(1.3)^{\mathrm{a}}$ & $182.6(2.6)^{\mathrm{z}}$ & $171.9(1.8)^{\mathrm{a}, \mathrm{z}}$ \\
\hline Captive & $109.7(1.1)^{\mathrm{b}}$ & $180.0(2.2)^{\mathrm{z}}$ & $152.5(1.8)^{\mathrm{b}, \mathrm{z}}$ \\
\hline
\end{tabular}

a,bignificant differences between wild and captive-reared individuals at the same phase of the reproductive cycle (Student's $t$ test, $P<0.05$ ).

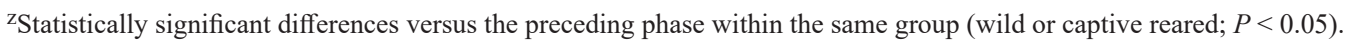
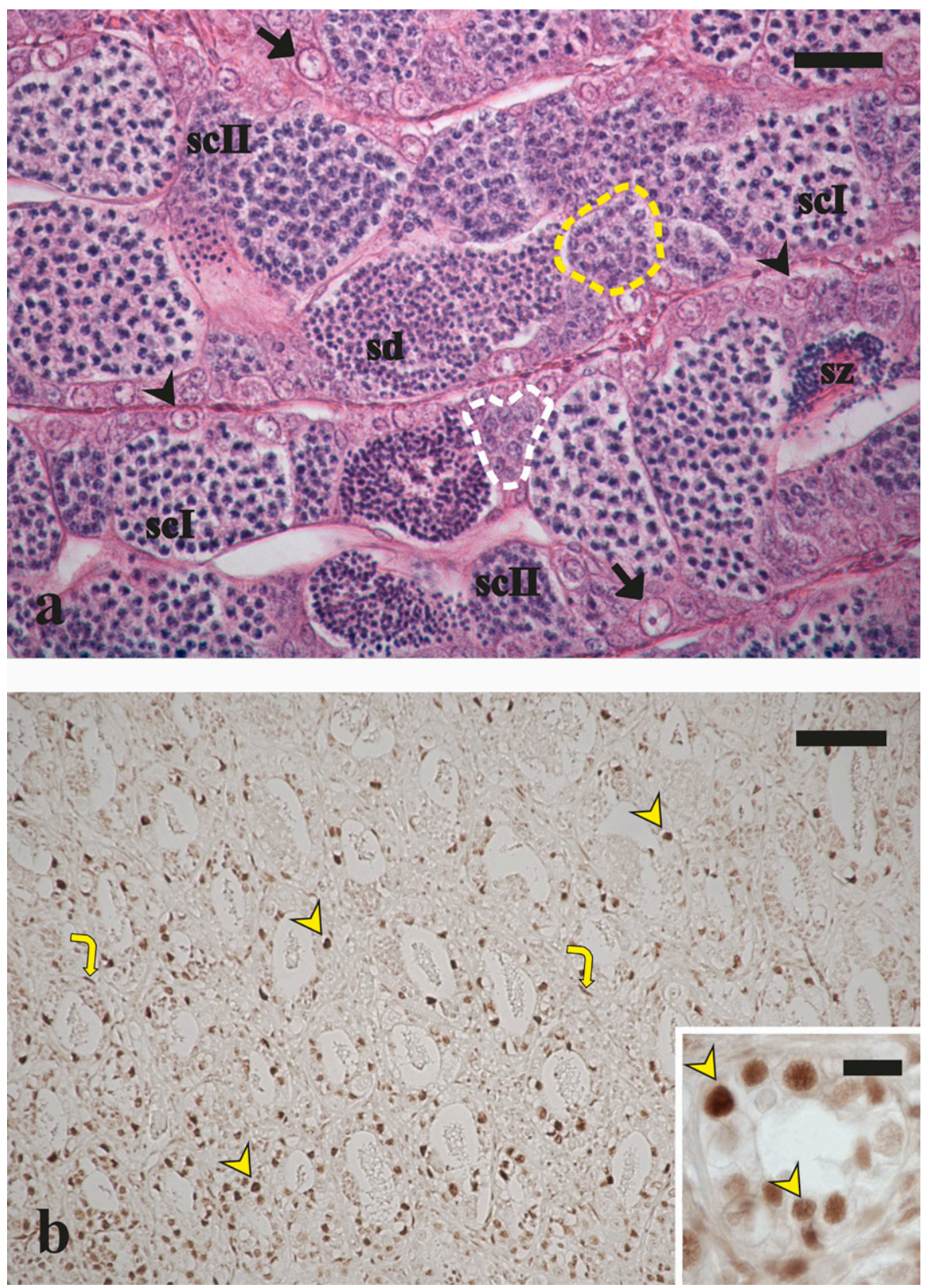

Figure 1. Micrographs of testis sections of greater amberjack sampled in different periods of the reproductive cycle. (a) Hematoxylin-eosin stained testis section from a specimen sampled in late May showing the different germ cell types. Magnification bar $=25 \mu \mathrm{m}$. Single A spermatogonia are indicated by black arrows and arrowheads; the latter point to cells likely corresponding to the intralobular anti-Pou5fl-positive spermatogonia (undifferentiated stem spermatogonia). (b) Peripheral region of the testis and detail of a seminiferous lobule (inset) of an individual sampled in early May, immunostained with anti-Pou5fl antibodies. Interlobular- (yellow curved arrows) and intralobular- (yellow arrowheads) positive cells are stained in brown. Magnification bar $=50 \mu \mathrm{m}$; in inset $=10 \mu \mathrm{m}$. The white dashed line encircles a type A spermatogonial cyst; the yellow dashed line encircles a type B spermatogonial cyst. sd = spermatid cyst; scI = primary spermatocyte cyst; scII = secondary spermatocyte cyst; $\mathrm{sz}=$ spermatozoa . 
within cysts or in the lumina of seminiferous lobules after cyst breakdown (Fig. 1a).

\section{Germ Cell Proliferation and Apoptosis}

Anti-PCNA immunostaining was observed in the nuclei of single A spermatogonia, spermatogonia contained in cysts, and primary spermatocytes (Fig. 2a). A weak staining of the nuclei of secondary spermatocytes was also observed, but these cells were not included in the quantitative analysis. The relative quantification of anti-PCNA-positive single A spermatogonia and spermatocysts throughout the sampling period is shown in Fig. 3. In wild greater amberjack, anti-PCNA-positive single A spermatogonia gradually decreased throughout the 3 examined phases, although a statistically significant change $(P<0.05)$ was detected only at the SPAWNING stage (Fig. 3a); anti-PCNA-positive spermatocysts decreased from the EARLY phase to the ADVANCED phase and then slightly increased in the SPAWNING phase $(P<0.05$; Fig. $3 b)$. In captivereared greater amberjack, the density of anti-PCNA single A spermatogonia was stable throughout the EARLY phase and the ADVANCED phase and dramatically decreased in the SPAWNING phase $(P<0.05$; Fig. 3a); a progressive decrease of anti-PCNA-positive spermatocysts density was observed in captivereared specimens throughout the examined phases of the reproductive cycle $(P<0.05$; Fig. $3 b)$. During the EARLY and SPAWNING phases, significantly higher $(P<0.05)$ densities of anti-PCNA-positive spermatocysts were observed in wild specimens compared with captive-reared specimens (Fig. 3b).

All the captive-reared and most of the wild greater amberjack showed TUNEL-positive germ cells. Apparently, the TUNEL reaction involved mainly single A spermatogonia, spermatogonia contained in cysts and primary spermatocytes (Fig. 2b). In wild males, the surface occupied by apoptotic germ cells significantly increased $(P<0.05)$ from the EARLY phase to the ADVANCED phase and remained stable thereafter, whereas in captive-reared individuals, the surface occupied by apoptotic cells was already high at the EARLY stage and remained unchanged during the 3 sampling phases and was comparable to the highest levels of the wild specimens (Fig. 4). The surface occupied by apoptotic cells was significantly higher $(P<$ $0.05)$ in captive-reared specimens than in wild specimens during the EARLY phase.

\section{7ß-Estradiol Plasma Levels}

The trend of $E_{2}$ plasma levels of wild and captivereared greater amberjack is shown in Fig. 5. Many- fold higher $(P<0.05) \mathrm{E}_{2}$ plasma levels were observed in captive-reared fish during the EARLY phase, but these levels significantly decreased in the following phases and were similar to those in wild fish.

\section{Sperm Quality in Captive-Reared Greater Amberjack}

The spermatozoa concentration of captive-reared greater amberjack was stable throughout the EARLY $\left(2.3 \pm 0.5 \times 10^{10} \mathrm{spz} / \mathrm{mL}\right)$ and ADVANCED $(3.6 \pm 0.4$ $\left.\times 10^{10} \mathrm{spz} / \mathrm{mL}\right)$ phases and significantly increased during the SPAWNING period $\left(4.6 \pm 0.6 \times 10^{10} \mathrm{spz} / \mathrm{mL}\right.$; ANOVA, $P<0.05)$. For all 3 sampling phases, the highest spermatozoa motility (\%) was reached within the first $20 \mathrm{~s}$ after activation and was followed by a progressive decrease until complete cessation of movement (Fig. 6a). However, sperm movement within the first $20 \mathrm{~s}$ presented variations linked to the sampling time, with the highest mean percentage of swimming spermatozoa recorded in the ADVANCED phase (59 $\pm 16.9 \%$ of motile spz) and the lowest mean value registered in the SPAWNING phase $(21 \pm 9.7 \%$ of motile spz). The mean VAP of the spermatozoa varied during the 3 different phases, with the highest mean value 10 $\mathrm{s}$ after activation recorded in the ADVANCED phase $(102.7 \pm 7.0 \mu \mathrm{m} / \mathrm{s})$ and the lowest mean VAP recorded during the SPAWNING phase $(36.5 \pm 3.3 \mu \mathrm{m} / \mathrm{s})$; the highest maximum value of individual velocity was reached during the ADVANCED phase $(164 \mu \mathrm{m} / \mathrm{s}$; Fig. 6b). Finally, a progressive significant decrease $(P$ $<0.05$ ) of sperm motility duration was observed from the EARLY phase to the SPAWNING phase (Fig. 6c).

The ATP level of captive-reared greater amberjack sperm was generally very low and close to the detection threshold for several samples (data not shown). A progressive, but not statistically significant, decrease of spermatozoa ATP concentration occurred from the EARLY phase $\left(4.7 \pm 1.7 \mathrm{nmol} / 10^{9} \mathrm{spz}\right)$ to the ADVANCED phase $\left(1.9 \pm 0.6 \mathrm{nmol} / 10^{9} \mathrm{spz}\right)$ and the SPAWNING phase $\left(1.2 \pm 0.4 \mathrm{nmol} / 10^{9} \mathrm{spz}\right)$. In terms of spermatozoa viability, there were significant variations among fish within each sampling time. Notwithstanding this individual variability, a significant increase $(P<0.05)$ of the proportion of dead and live spermatozoa was observed from the ADVANCED phase to the SPAWNING phase, whereas the proportion of dying spermatozoa did not significantly vary (Fig. 7).

\section{DISCUSSION}

The negative influence of captivity on reproductive function has been widely demonstrated in all 

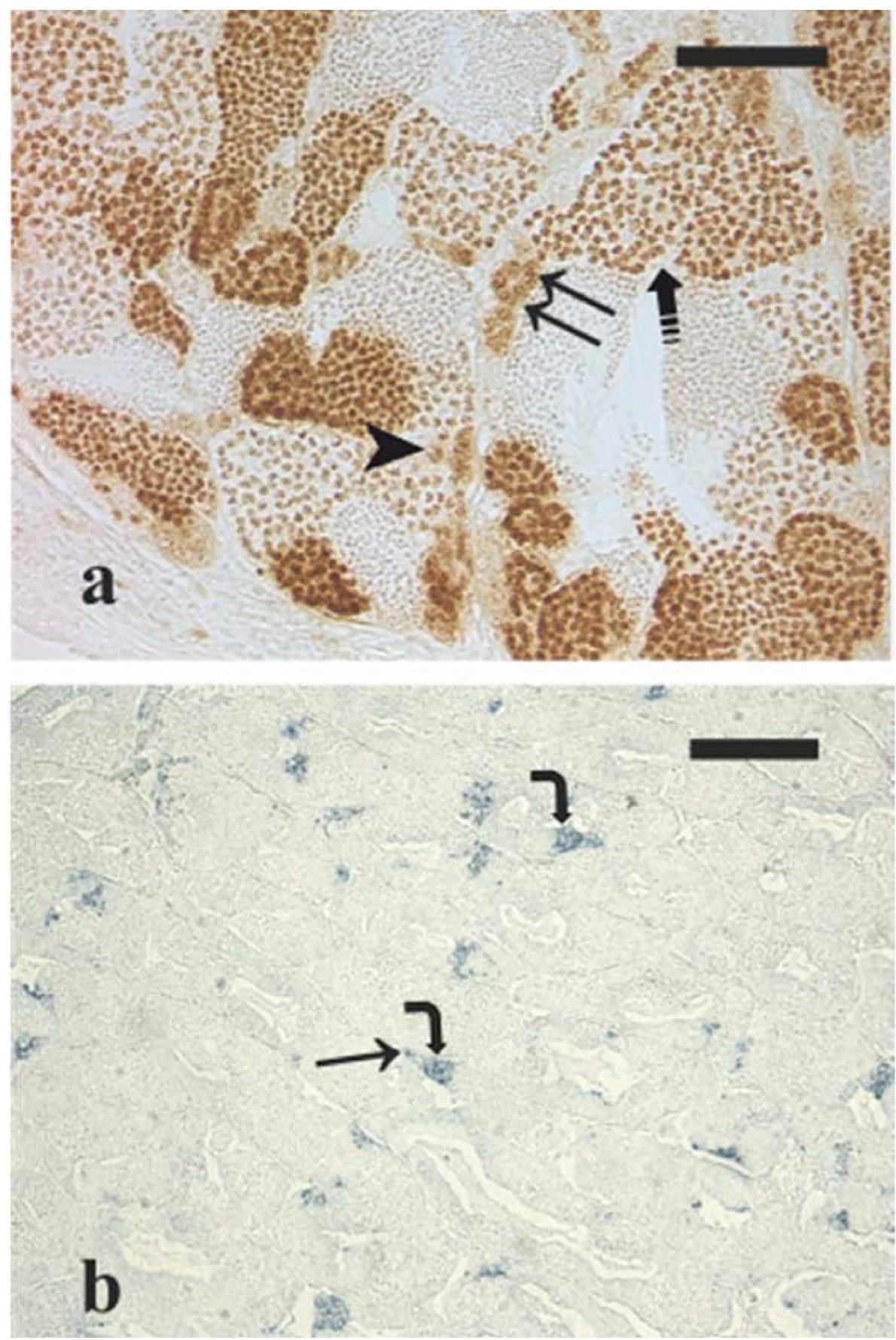

Figure 2. Micrographs of greater amberjack testis sections sampled in different periods of the reproductive cycle. (a) Testis section of a wild individual sampled in early May, immunostained with antibodies against the proliferating cell nuclear antigen (PCNA), which stains brown the nuclei of proliferating cells. Magnification bar $=40 \mu \mathrm{m}$. Arrowheads indicate an anti-PCNA-positive single spermatogonium, double arrows indicate an anti-PCNApositive spermatogonial cyst, and dashed arrows indicate a primary spermatocyte cyst. (b) Testis section of a captive-reared individual sampled during late April stained with the terminal deoxynucleotidyl transferase-mediated 2'-deoxyuridine 5'-triphosphate nick end labeling (TUNEL) method, with apoptotic cells appearing as dark blue dots. Magnification $b a r=150 \mu \mathrm{m}$. Arrows indicate a TUNEL-positive single spermatogonium and curved arrows indicate a TUNEL-positive spermatocysts.

vertebrate classes, including fishes (Zohar and Mylonas, 2001; Corriero et al., 2009, 2011; Mylonas et al., 2010; Schreck, 2010; Rosenfeld et al., 2012; Zupa et al., 2013). As part of a larger effort to improve our understanding of the gametogenesis dysfunctions recently reported in greater amberjack maintained in captivity (Zupa et al., 2017), the present study adds further information on the effects of confinement in captivity on greater amberjack germ cell proliferation and apoptosis as well as on sperm quality. Recently, Zupa et al. (2017) reported scarce gonad development and precocious cessation of the spermatogenic activity as well as abnormal testosterone (T), 11-ketotestosterone (11-KT), and 17,20ß-dihydroxy-4-pregnen-3-one 
(a)

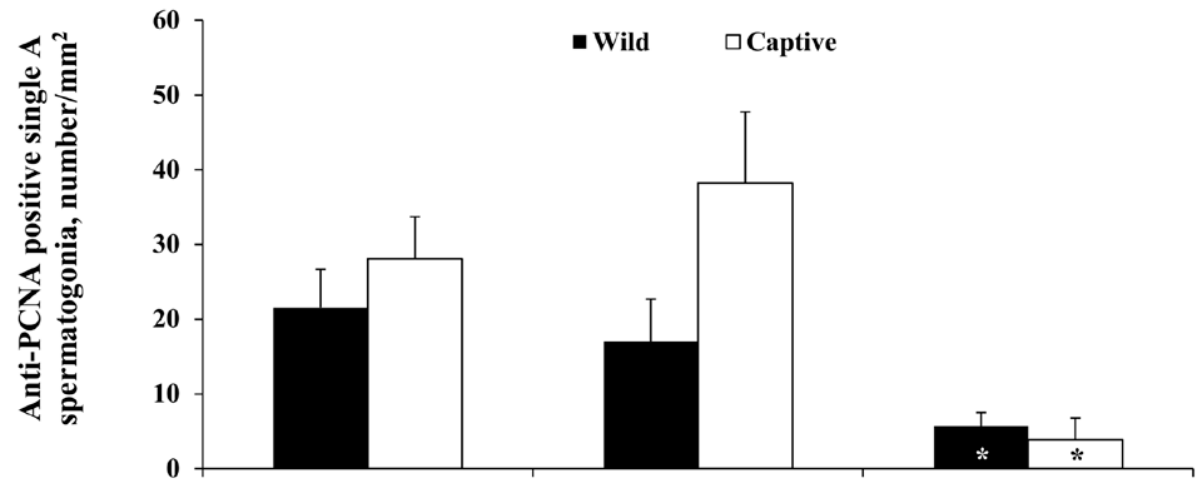

(b)

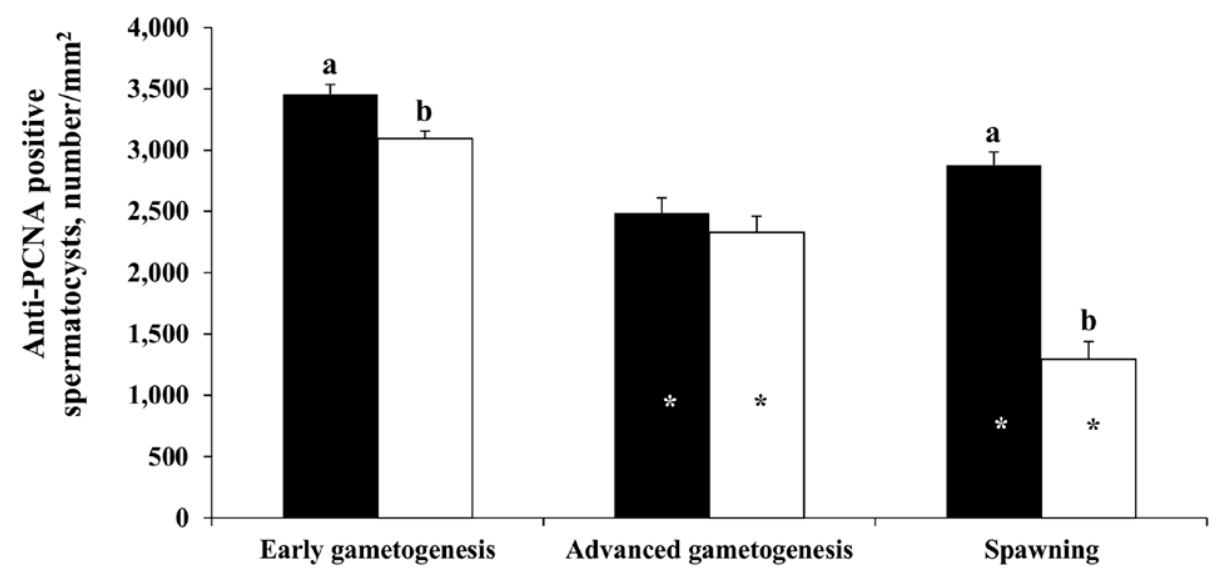

Figure 3. Changes in mean $( \pm \mathrm{SE})$ anti-proliferating cell nuclear antigen (PCNA)-positive germ cell density in wild and captive-reared greater amberjack males during the reproductive season. (a) Anti-PCNA-positive single A spermatogonia. (b) Anti-PCNA-positive spermatocysts. *White asterisks indicate statistically significant differences (Student's $t$-test, $P<0.05$ ) versus the preceding phase in wild fish. *Black asterisks indicate statistically significant differences (Student's $t$ test, $P<0.05$ ) versus the preceding phase in captive fish. ${ }^{\mathrm{a}, \mathrm{b}}$ Different letters represent significant differences between wild and captive individuals within the same sampling phase (Student's $t$ test, $P<0.05$ ).

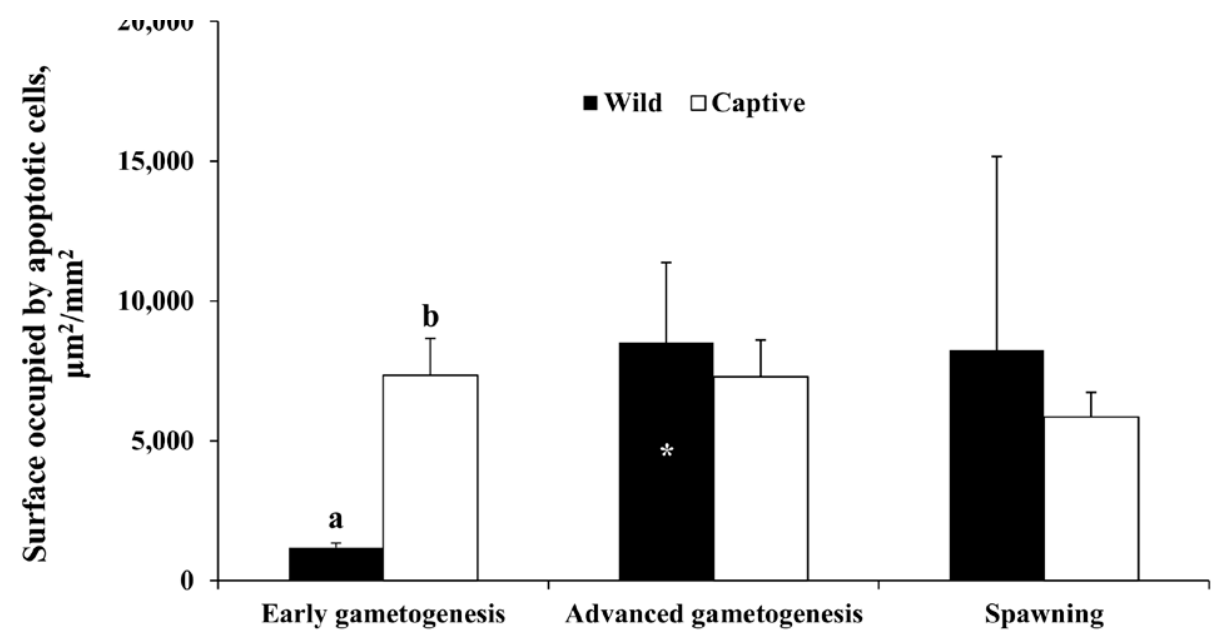

Figure 4. Changes in mean $( \pm \mathrm{SE})$ surface occupied by apoptotic germ cells in wild and captive-reared male greater amberjack sampled during the reproductive season in the Mediterranean Sea. *A white asterisk indicates a statistically significant difference (Student's $t$ test, $P<0.05$ ) versus the preceding phase in wild fish. ${ }^{\mathrm{a}, \mathrm{b}}$ Different letters indicate a significant difference between wild and captive individuals sampled in the same phase (Student's $t$-test, $P<0.05)$. 


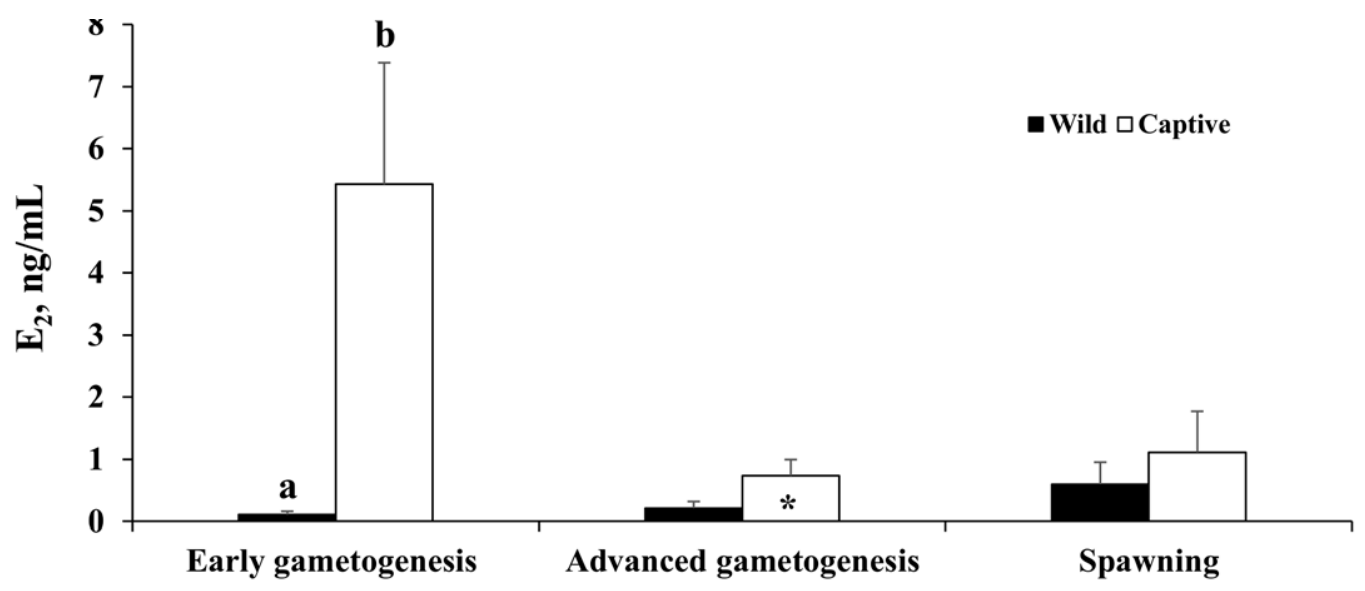

Figure 5. Mean $( \pm \mathrm{SE})$ plasma $17 \beta$-estradiol $\left(\mathrm{E}_{2}\right)$ concentrations in wild and captive-reared greater amberjack males sampled during the reproductive season in the Mediterranean Sea. ${ }^{*}$ The asterisk indicates a statistically significant difference (Student's $t$-test, $P<0.05$ ) versus the preceding phase. a,b Different letters indicate significant differences between wild and captive individuals sampled in the same phase (Student's $t$ test, $P<0.05$ ).

(17,20ß-P) plasma levels. On the other hand, vitellogenesis proceeded without any noticeable impairment (C. Pousis, unpublished data). The present study suggests that the earlier-reported dysfunctional spermatogenesis of captive-reared greater amberjack involves also smaller seminiferous lobules in the EARLY and SPAWNING phases, an altered pattern of germ cell proliferation, and an increased number of apoptotic germ cells as well as abnormally high $\mathrm{E}_{2}$ plasma concentrations during the EARLY spermatogenesis phase.

The smaller seminiferous lobules of captivereared greater amberjack reported here were correlated with a lower GSI and indicate a reduced capacity of the testes to develop and reach full maturation. In turn, this reduced capacity to reach full gonad development was likely related to the lower sex steroid ( $\mathrm{T}$, $11-\mathrm{KT}$, and 17,20ß-P) plasma concentrations reported by Zupa et al. (2017). In terms of germ cell proliferation, the basic histology and immunohistochemistry used in the present study made it possible to distinguish and describe 3 different type A spermatogonia, of which 2 types were single cells and a third type was represented by cells being part of spermatocysts, type B spermatogonia, primary and secondary spermatocytes, spermatids, and spermatozoa. Only 1 of the 2 type A single spermatogonia immunoreacted with anti-Pou5f1 antibodies, revealing stemness properties. This stem spermatogonium type, likely corresponding to the type A undifferentiated* spermatogonium of the classification used by Schulz et al. (2010), is responsible for germ cell self-renewal. The second type of A single spermatogonia found in greater amberjack is non-stem spermatogonia, whose activity is likely related to differentiation and rapid proliferation toward meiosis. This cell type may correspond to the type A undifferentiated spermatogonia referred to by Schulz et al. (2010), although these authors did not exclude a residual stem capacity for this cell type. In greater amberjack testes, anti-PCNA-positive undifferentiated single type A spermatogonia (both positive and negative cells to the stemness marker Pou5f1), differentiated spermatogonia (type $\mathrm{A}$ and $\mathrm{B}$ spermatogonia that are part of cysts), and primary spermatocytes were detected during all investigated reproductive phases.

In the present study, the density of proliferating single spermatogonia remained at the highest levels throughout the EARLY and ADVANCED phases and dramatically decreased during the SPAWNING phase, with differences between wild and captive-reared individuals. This trend of proliferating activity of single spermatogonia during the reproductive season is consistent with the decreasing trend of $\mathrm{T}$ and 11-KT plasma levels during the SPAWNING phase (Zupa et al., 2017). The absence of significant differences in the density of proliferating single spermatogonia between wild and captive-reared greater amberjack is apparently in contrast with the lower T and 11-KT plasma levels observed in fish kept in captivity (Zupa et al., 2017). However, this apparent incongruence may be explained by 1) an increased spermatogonial self-renewal activity stimulated by abnormally high $\mathrm{E}_{2}$ levels during the EARLY phase and/or 2) a diminished capacity of spermatogonia to proceed toward meiosis (lower density of PCNA-positive spermatocytes; see below), resulting in a comparatively higher number of less-developed germ cells in captive-reared fish. The lower spermatogonial capacity of captive-reared fish to proceed toward meiosis might have resulted from the combined effects of higher $\mathrm{E}_{2}$ and lower T/11-KT plasma concentrations. In fact, although $\mathrm{E}_{2}$ in male fish stimulates spermatogonial self-renewal (Miura et al., 1999; Schulz and Miura, 2002; Schulz et al., 2010), supraphysiological concentrations of this hormone inhibit spermatogenesis through negative feedback ef- 


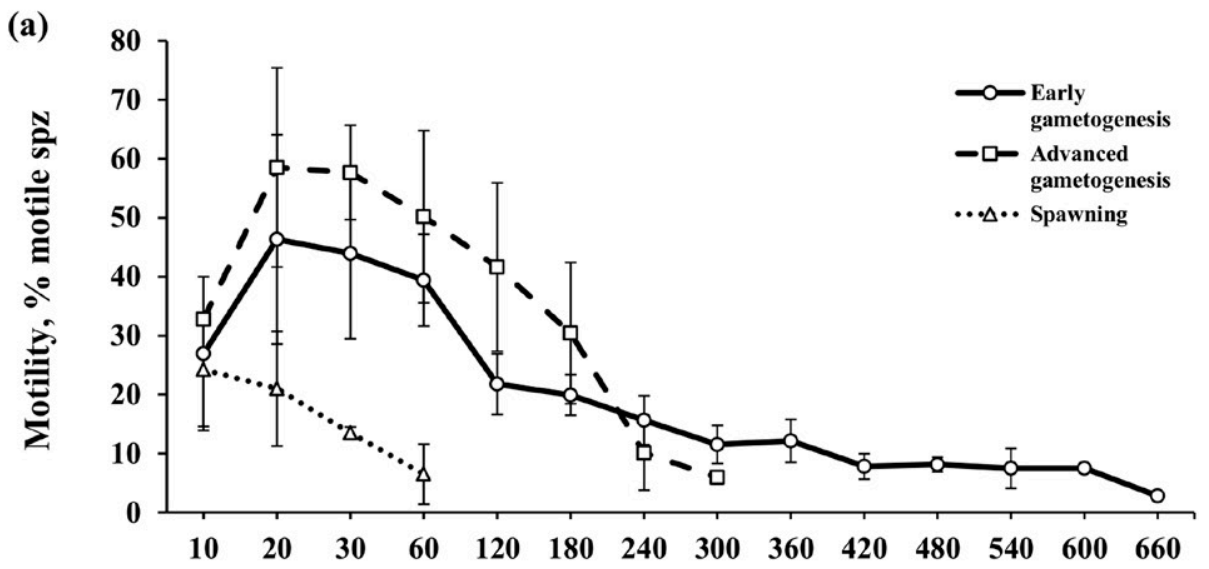

Time after activation (s)

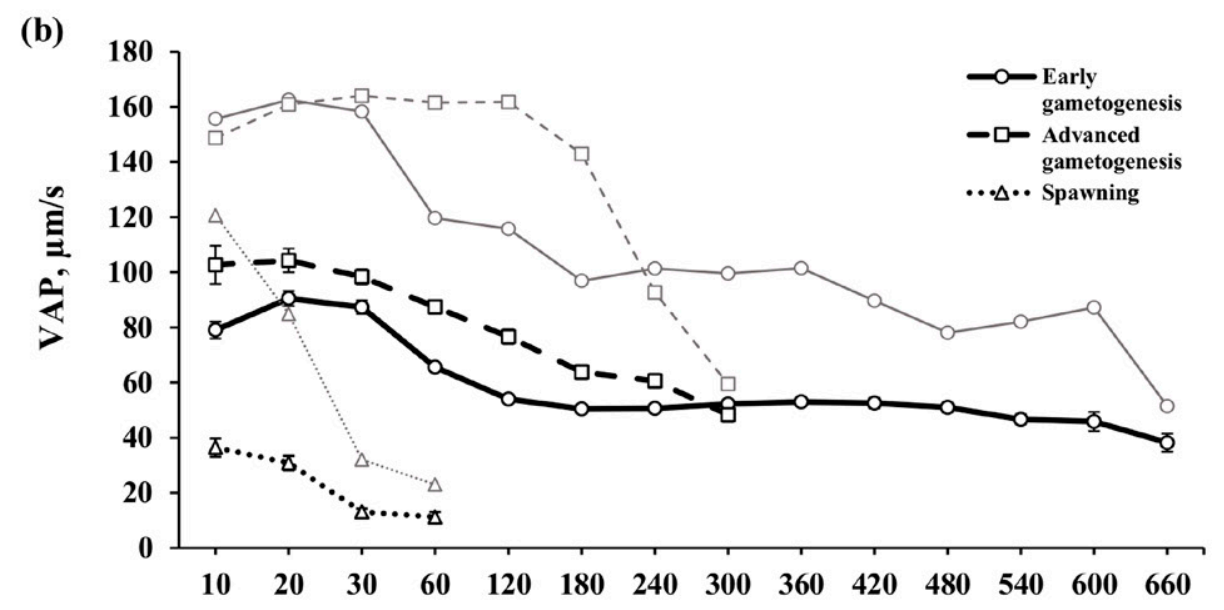

Time after activation (s)

(c)

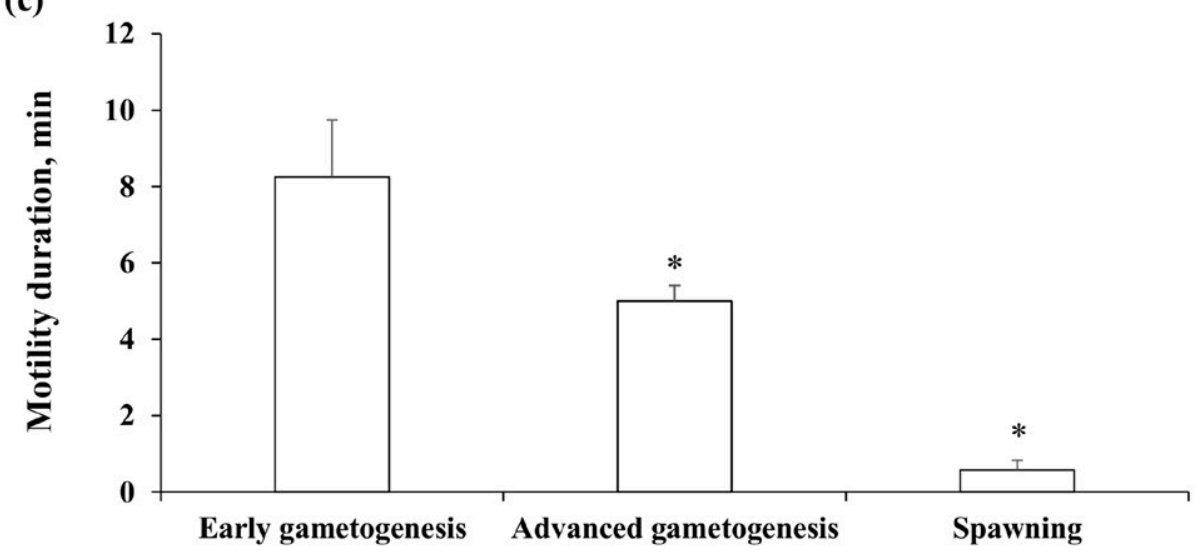

Figure 6. (a) Sperm motility percentage, (b) average path velocity (VAP), and (c) motility duration in captive-reared greater amberjack during 3 phases of the reproductive season in the Mediterranean Sea. In (b), black lines illustrate the mean VAP of sperm population for each phase, whereas gray lines show the maximum value of individual sperm velocity recorded. *In (c), black asterisks indicate significant differences versus the preceding phase (ANOVA, $P<0.05)$. spz $=$ spermatozoa

fects on the brain and the pituitary, involving downregulation of the testicular androgen production capacity (Schulz and Nóbrega, 2011).

In captive-reared individuals, the density of spermatocysts containing proliferating type $\mathrm{A}$ and $\mathrm{B}$ spermatogonia plus primary spermatocytes was lower than in wild fish in the EARLY and SPAWNING stages and showed a progressive decrease from the EARLY phase to the SPAWNING phase. This is in agreement with previous observations showing that captive-reared greater amberjack were already in a spent condition during the SPAWNING phase of the wild population 


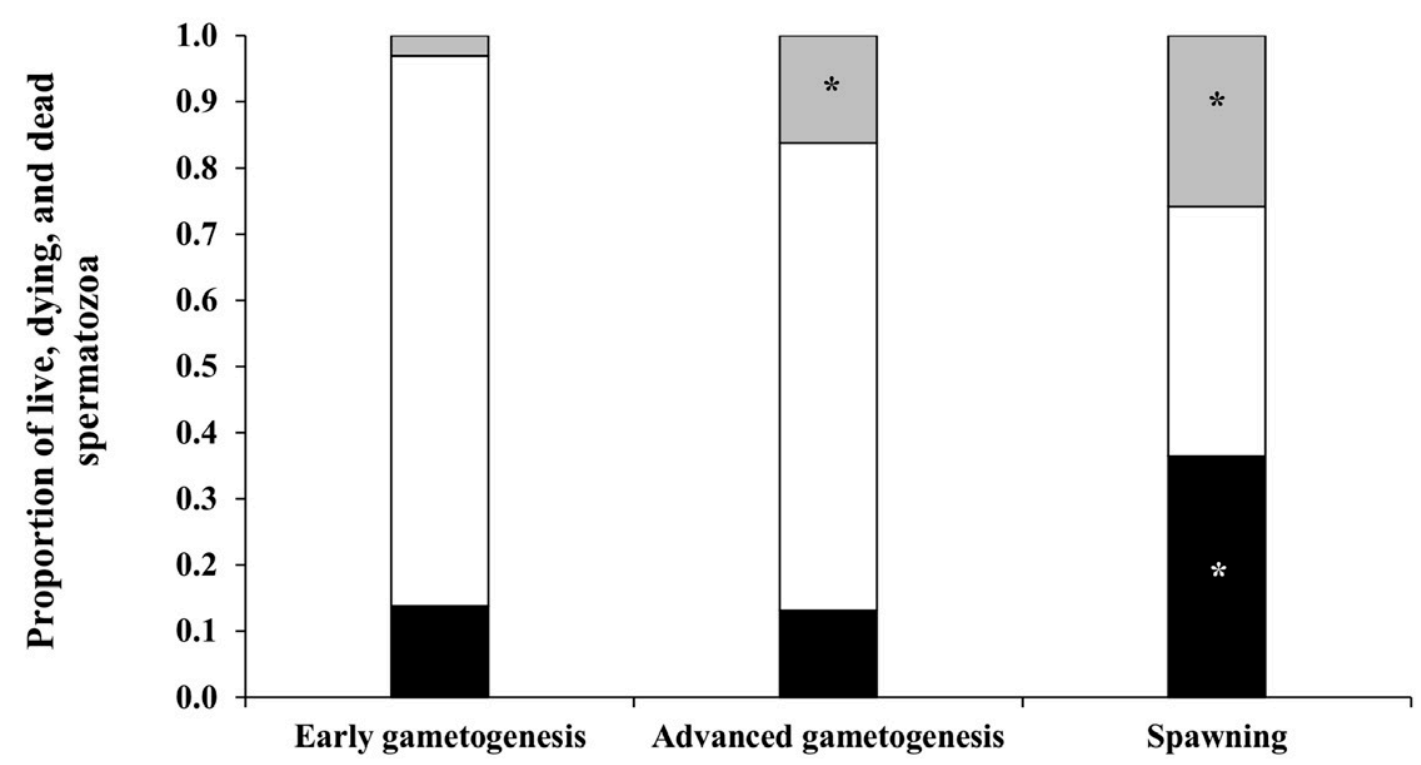

Figure 7. Proportion of live, dying, and dead spermatozoa in captive-reared greater amberjack during 3 phases of the reproductive season in the Mediterranean Sea. *Black and white asterisks indicate significant differences versus the preceding phase within the same spermatozoa condition (ANOVA, $P<0.05)$.

and their T, 11-KT and 17,20ß-P plasma levels were abnormally low (Zupa et al., 2017). Besides promoting germ cell proliferation, spermiogenesis, and spermiation, androgens have been proposed to act as survival factors for germ cells, both in mammals (Young and Nelson, 2001) and in fish (Corriero et al., 2009; Zupa et al., 2013, 2014). Withdrawal of androgens induces apoptosis in the testis (Nandi et al., 1999; Woolveridge et al., 1999), and reintroduction of steroid hormones can reduce apoptotic cell death (Nandi et al., 1999). In the present study, apoptotic germ cells, spermatogonia and primary spermatocytes, were observed in all specimens analyzed. In wild greater amberjack, apoptotic germ cell density was highest in the ADVANCED and SPAWNING phases, corroborating the physiological role of apoptosis in the quantitative control of germ cell populations and in the prevention of aberrant germ cell development, as proposed for other large pelagic fish such as the Atlantic bluefin tuna (Thunnus thynnus; Corriero et al., 2009; Zupa et al., 2013, 2014) and the swordfish Xiphias gladius; Corriero et al., 2007). In captive-reared greater amberjack, a high density of germ cell apoptosis was observed at the beginning of the reproductive season (EARLY phase). The high incidence of apoptosis at the onset of spermatogenesis, far from playing a physiological role, was likely correlated to the low androgen and high $\mathrm{E}_{2}$ plasma levels reported in captive individuals and may have been co-responsible for the reduced sperm concentration (see below). Incidentally, the administration of high doses of $E_{2}$ in male gilthead seabream (Sparus aurata) induced apoptosis of spermatogonia (Chaves-Pozo et al., 2007).

In a mammalian model (rat), gonadotrophin withdrawal following hypophysectomy and the consequent decline of sex steroid circulating levels were found to induce testicular atrophy, reduction of germ cell proliferation, and increase of apoptosis (Tapanainen et al., 1993). In wild-caught captive-reared Atlantic bluefin tuna, an increase of 11-KT plasma levels produced by gonadotropin-releasing hormone agonist (GnRHa) administration stimulated spermatogonial proliferation and reduced the rate of apoptotic germ cells (Corriero et al., 2009). The observed low androgen levels found in captive-reared greater amberjack may have been caused by a reduced release of gonadotropins from the pituitary and/or an altered steroid metabolism. In fact, testes of greater amberjack reared in captivity were found to have a much reduced amount of arachidonic acid (Zupa et al., 2017), a molecule that stimulates testosterone production by elevating cyclic adenosine monophosphate levels in a dose-dependent manner (Mercure and Van Der Kraak, 1995, 1996). Moreover, in birds (Newman et al., 2008; Dickens et al., 2011) and mammals (Williams, 2012), the exposure to different types of stressing factors can result in aromatase upregulation with the consequent increase of $E_{2}$ and decrease of androgens.

One objective of this study was to assess if the above-described dysfunctions resulted in decreased sperm quality. Unfortunately, due to the difficulties of operating in the field, it was not possible to collect and analyze sperm from wild individuals, which would 
have represented a valued reference for the assessment of sperm taken from captive-reared specimens. Contrary to previous sperm sampling attempts performed in Croatia (Kožul et al., 2001a), but consistent with attempts made in Greece (Mylonas et al., 2004), in the present study, it was not possible to take sperm by stripping captive-reared greater amberjack. This failure is believed to be due to the strong abdominal musculature of this species (Mylonas et al., 2004) and could be exacerbated by the lack of significant testicular hydration. It has been observed in various captive-reared greater amberjack broodstocks that it is not possible to collect sperm by abdominal stripping even from males belonging to actively spawning broodstocks that produce large numbers of fertilized eggs daily (Fakriadis et al., 2017). In the case of the present study, however, our failure to collect sperm by stripping was probably more related to a lack of significant testicular hydration. Indeed, during the dissection of the testes, it was observed that the vasa deferentia were not full of sperm and that only a direct strong squeezing of the testes allowed sperm to be obtained, so that the following discussion actually refers to intratesticular sperm, which might lack complete maturation and hydration and whose count could potentially be affected by the presence of somatic cells, immature germ cells, and cellular debris that can be mistaken for spermatozoa. The sperm concentration of captive-reared greater amberjack measured in this study was in the upper range of marine fish species (Suquet et al., 1994; Cosson et al., 2008b), which is consistent with a lack of hydration that, if realized, would have resulted in a physiological reduction of this parameter toward the spawning season. To our knowledge, the observed increase of sperm concentration during the SPAWNING phase has never been reported in any other fish species; moreover, the histological analysis reported by Zupa et al. (2017) showed that although these specimens had ceased their spermatogenic activity, they still retained a moderate number of luminal spermatozoa in the testes. Altogether, these observations seem to support the hypothesis of the lack of proper sperm hydration in captive-reared greater amberjack, probably in response to low sex steroid levels. It is known that sperm hydration with seminal fluid and release via the sperm duct are under endocrine control, and a key role in this process and in the intensification of sperm motility is played by 17,20ß-P (Schulz and Miura, 2002; Milla et al., 2008; Scott et al., 2010), whose plasma levels were reported to be abnormally low in captive-reared greater amberjack during the ADVANCED and SPAWNING phases (Zupa et al., 2017).

The sperm of captive-reared greater amberjack analyzed in the present study showed a general motil- ity pattern similar to those of other fishes, with high initial spermatozoa motility percentage and velocity at activation followed by a decrease of both parameters until all movement ceased (Cosson et al., 2008a,b). However, despite the fact that the velocity of the faster spermatozoa in captive-reared greater amberjack sperm was similar to that of other species, such as the European sea bass (Dicentrarchus labrax; Fauvel et al., 2012) and the Atlantic bluefin tuna (Zupa et al., 2013), the maximum sperm motility recorded (about $60 \%$ of motile spermatozoa during the ADVANCED phase) was lower compared with most other studied species (Cosson et al., 2008b), and the percentage of motile spermatozoa, motility duration, and velocity drastically declined during the SPAWNING phase. Moreover, the sperm ATP content decreased in captive-reared greater amberjack from the EARLY phase to the SPAWNING phase. The ATP content is widely used as a sperm quality marker (Cosson et al., 2008b; Fauvel et al., 2010), because it is a key limiting factor for maintaining motility (Christen et al., 1987; Cosson, 2010; Ulloa-Rodríguez et al., 2017). Therefore, the decrease of energy content observed in captivereared greater amberjack in the present study might explain, at least partially, the lower percentage of motile spermatozoa. Finally, the assessment of sperm membrane integrity from captive-reared fish demonstrated that the percentage of dead spermatozoa significantly increased from the ADVANCED phase to the SPAWNING phase, which is consistent with the lack of sperm hydration and, presumably, ejaculation and consequent sperm ageing.

As to the underlying cause of the abovementioned dysfunctions in sex hormone levels, germ cell proliferation, and apoptosis, we can only speculate at this stage. The fish were acclimated for $2 \mathrm{yr}$ in the facilities and were maintained in a large-volume sea cage $\left(640 \mathrm{~m}^{3}\right.$ rectangular shape) at low stocking densities $\left(<1 \mathrm{~kg} / \mathrm{m}^{3}\right)$. The site has excellent water circulation and low aquaculture production capacity $(<500$ metric tons/yr) and the fish showed a good feeding behavior and growth rate during the 2-yr acclimation period, increasing in weight from 5 to $7 \mathrm{~kg}$ to 9 to $15 \mathrm{~kg}$. Water temperatures during the year were typical of the Mediterranean Sea, ranging between 14.3 and $30.1^{\circ} \mathrm{C}$. Apart from being maintained in a captive environment, preventing any migration, and being fed a commercial extruded broodstock diet as opposed to forage fish, the breeders were exposed to very low stress conditions during the whole year. So it is conceivable that the offered food was not optimal for reproductive maturation and required some formulation adjustment, as suggested by Zupa et al. (2017), although it cannot be said that it was grossly inappropriate. In fact, another 
broodstock of the same source and age was maintained under identical conditions in the same facility, and during June, it reached advanced stages of gametogenesis to be able to be induced to spawn and produce fertilized eggs using a GnRHa therapy (Mylonas et al., 2017). This suggests that it is possible for captivereared greater amberjack to undergo gametogenesis to an extent that viable gametes (eggs and sperm) can be spawned, producing viable progeny. Although similar evaluations of spermatogenesis were not undertaken on the males of this latter spawning stock, the fact that fertilized eggs were produced indicates that adequate amounts of viable sperm were produced by the males, which were also capable of engaging in normal breeding activities to fertilize the eggs produced by the females, albeit after an exogenous GnRHa therapy.

One aspect of the rearing conditions of the fish in the present study that might have exacerbated the progress of an already dysfunctional spermatogenesis was the management/handling stress to which the fish were exposed during the sampling process. Due to facility limitations, all fish used for the 3 samplings were maintained in the same sea cage. As a result of the sampling procedure (see Materials and Methods), except for the fish sacrificed during the first sampling, all other fish were exposed to a certain amount of handling or management stress a few weeks prior to their being sampled for the study. We believe that this handling or management stress during the reproductive period was responsible for the deterioration of the spermatogenesis, which was already impaired at the beginning of the reproductive cycle (high plasma $\mathrm{E}_{2}$ concentration and germ cell apoptosis during the EARLY phase).

In conclusion, the present study demonstrated that rearing in captivity affected spermatogenesis in greater amberjack from its EARLY phase, when a high level of germ cell apoptosis was observed. Handling or mild management probably had an additional negative effect on spermatogenesis, resulting in a constant reduction of the rate of spermatogonia entering meiosis, which resulted in a precocious cessation of the spermatogenic activity. As a consequence of this spermatogenesis impairment, greater amberjack confined in captivity showed low sperm quality, in terms of sperm density and motility and velocity as well as ATP content and membrane integrity. This study provides further information on the occurrence of severe reproductive dysfunctions in captive-reared greater amberjack males reported by Zupa et al. (2017) and further supports the need for an improvement of rearing technology. In particular, handling procedures minimizing stress could be effective in alleviating reproductive deficiencies.

\section{LITERATURE CITED}

Beirão, J., F. Soares, P. Herraez, M. T. Dinis, and E. Cabrita. 2009. Sperm quality evaluation in Solea senegalensis during the reproductive season at cellular level. Theriogenology 72:12511261. doi:10.1016/j.theriogenology.2009.07.021

Berkovich, N., A. Corriero, N. Santamaria, C. C. Mylonas, R. Vassallo-Aguis, F. de la Gándara, I. Meiri-Ashkenazi, V. Zlatnikov, H. Gordin, C. R. Bridges, and H. Rosenfeld. 2013. Intra-pituitary relationship of follicle stimulating hormone and luteinizing hormone during pubertal development in Atlantic bluefin tuna (Thunnus thynnus). Gen. Comp. Endocrinol. 194:10-23. doi:10.1016/j.ygcen.2013.08.005

Bobe, J., and C. Labbé. 2010. Egg and sperm quality in fish. Gen. Comp. Endocrinol. 165:535-548. doi:10.1016/j.ygcen.2009.02.011

Boryshpolets, S., B. Dzyuba, V. Stejskal, and O. Linhart. 2009. Dynamics of ATP and movement in Eurasian perch (Perca fluviatilis L.) sperm in conditions of decreasing osmolality. Theriogenology 72:851-859. doi:10.1016/j.theriogenology.2009.06.005

Cabrita, E., V. Robles, and P. Herráez. 2009. Sperm quality assessment. In: E. Cabrita, V. Robles, and P. Herráez, editors, Methods in reproductive aquaculture. Marine and freshwater species. CRC Press Taylor \& Francis Group, Boca Raton, FL. p. 93-148.

Chaves-Pozo, E., S. Liarte, L. Vargas-Chacoff, A. García-López, V. Mulero, J. Meseguer, J. M. Mancera, and A. García-Ayala. 2007. 17Beta-Estradiol triggers postspawning in spermatogenically active gilthead seabream (Sparus aurata L.) males. Biol. Reprod. 76:142-148. doi:10.1095/biolreprod.106.056036

Christen, R., J. L. Gatti, and R. Billard. 1987. Trout sperm motility: The transient movement of trout sperm is related to changes in the concentration of ATP following the activation of the flagellar movement. Eur. J. Biochem. 166:667-671. doi:10.1111/j.1432-1033.1987.tb13565.x

Corriero, A., S. Desantis, C. R. Bridges, D. E. Kime, P. Megalofonou, N. Santamaria, F. Cirillo, G. Ventriglia, A. Di Summa, M. Deflorio, F. Campobasso, and G. De Metrio. 2007. Germ cell proliferation and apoptosis during different phases of swordfish (Xiphias gladius L.) spermatogenetic cycle. J. Fish Biol. 70:8399. doi:10.1111/j.1095-8649.2006.01257.x

Corriero, A., A. Medina, C. C. Mylonas, C. R. Bridges, N. Santamaria, M. Deflorio, M. Losurdo, R. Zupa, H. Gordin, F. de la Gándara, A. Belmonte Ríos, C. Pousis, and G. De Metrio. 2009. Proliferation and apoptosis of male germ cells in captive Atlantic bluefin tuna (Thunnus thynnus L.) treated with gonadotropin-releasing hormone agonist (GnRHa). Anim. Reprod. Sci. 116:346-357. doi:10.1016/j.anireprosci.2009.02.013

Corriero, A., R. Zupa, G. Bello, C. C. Mylonas, M. Deflorio, S. Genovese, G. Basilone, G. Buscaino, G. Buffa, C. Pousis, G. De Metrio, and N. Santamaria. 2011. Evidence that severe acute stress and starvation induce rapid atresia of vitellogenic follicles in Atlantic bluefin tuna, Thunnus thynnus (L.) (Osteichthyes: Scombridae). J. Fish Dis. 34:853-860. doi:10.1111/j.13652761.2011.01303.x

Cosson, J. 2010. Frenetic activation of fish spermatozoa flagella entails short-term motility, portending their precocious decadence. J. Fish Biol. 76:240-279. doi:10.1111/j.10958649.2009.02504.x

Cosson, J., A.-L. Groison, M. Suquet, C. Fauvel, C. Dreanno, and R. Billard. 2008a. Marine fish spermatozoa: Racing ephemeral swimmers. Reproduction 136:277-294. doi:10.1530/REP-070522 
Cosson, J., A.-L. Groison, M. Suquet, C. Fauvel, C. Dreanno, and R. Billard. 2008b. Studying sperm motility in marine fish: An overview on the state of the art. J. Appl. Ichthyology 24:460 486. doi:10.1111/j.1439-0426.2008.01151.x

Dickens, M. J., C. A. Cornil, and J. Balthazart. 2011. Acute stress differentially affects aromatase activity in specific brain nuclei of adult male and female quail. Endocrinology 152:4242-4251. doi:10.1210/en.2011-1341

Fakriadis, I., F. Lisi, I. Sigelaki, M. Papadaki, A. Raftopoulos, and C. C. Mylonas. 2017. Spawning kinetics of greater amberjack Seriola dumerili in response to multiple GnRHa injections or implants. In: Aquaculture Europe 2017, Dubrovnik, Croatia, October 16-20, 2017. (Accepted oral presentation; in press.)

Fauvel, C., S. Boryshpolets, J. Cosson, J. G. Wilson Leedy, C. Labbé, P. Haffray, and M. Suquet. 2012. Improvement of chilled seabass sperm conservation using a cell culture medium. J. Appl. Ichthyology 28:961-966. doi:10.1111/jai.12071

Fauvel, C., M. Suquet, and J. Cosson. 2010. Evaluation of fish sperm quality. J. Appl. Ichthyology 26:636-643. doi:10.1111/ j.1439-0426.2010.01529.x

Garcia, A., M. V. Diaz, and B. Agulleiro. 2001. Induccion hormonal de la puesta y desarrollo embrionario de la seriola Mediterranea (Seriola dumerilii, Risso). (In Spanish.) Monogr. Inst. Canar. Cienc. Mar. 4:561-566.

Izquierdo, M. S., H. Fernandez-Palacios, and A. G. J. Tacon. 2001. Effect of broodstock nutrition on reproductive performance of fish. Aquaculture 197:25-42. doi:10.1016/S00448486(01)00581-6

Kožul, V., B. Skaramuca, B. Glamuzina, N. Glavić, and P. Tutman. 2001a. Comparative gonadogenesis and hormonal induction of spawning of cultured and wild Mediterranean amberjack (Seriola dumerili, Risso 1810). Sci. Mar. 65:215-220. doi:10.3989/ scimar.2001.65n3215

Kožul, V., B. Skaramuca, M. Kraljević, J. Dulčić, and B. Glamuzina. 2001b. Age, growth and mortality of the Mediterranean amberjack Seriola dumerili (Risso 1810) from the south-eastern Adriatic Sea. J. Appl. Ichthyology 17:134-141. doi:10.1046/ j.1439-0426.2001.00301.x

Lacerda, S. M. D. S. N., G. M. J. Costa, and L. R. de França. 2014. Biology and identity of fish spermatogonial stem cell. Gen. Comp. Endocrinol. 207:56-65. doi:10.1016/j.ygcen.2014.06.018

Mandich, A., A. Massari, S. Bottero, P. Pizzicori, H. Goos, and G. Marino. 2004. Plasma sex steroid and vitellogenin profiles during gonad development in wild Mediterranean amberjack ( $\mathrm{Se}$ riola dumerilii). Mar. Biol. 144:127-138. doi:10.1007/s00227003-1185-6

Mercure, F., and G. Van Der Kraak. 1995. Inhibition of gonadotropin-stimulated ovarian steroid production by polyunsaturated fatty acids in teleost fish. Lipids 30:547-554. doi:10.1007/ BF02537030

Mercure, F., and G. Van Der Kraak. 1996. Mechanisms of action of free arachidonic acid on ovarian steroid production in the goldfish. Gen. Comp. Endocrinol. 102:130-140. doi:10.1006/ gcen.1996.0054

Micale, V., G. Maricchiolo, and L. Genovese. 1999. The reproductive biology of the amberjack, Seriola dumerilii (Risso, 1810). I. Oocyte development in captivity. Aquacult. Res. 30:349-355. doi:10.1046/j.1365-2109.1999.00336.x
Milla, S., X. Terrien, A. Sturm, F. Ibrahim, F. Giton, J. Fiet, P. Prunet, and F. Le Gac. 2008. Plasma 11-deoxycorticosterone (DOC) and mineralocorticoid receptor testicular expression during rainbow trout Oncorhynchus mykiss spermiation: Implication with 17alpha, 20beta-dihydroxyprogesterone on the milt fluidity? Reprod. Biol. Endocrinol. 6:19. doi:10.1186/14777827-6-19

Miura, T., C. Miura, T. Ohta, M. R. Nader, T. Todo, and K. Yamauchi. 1999. Estradiol-17 $\beta$ stimulates the renewal of spermatogonial stem cells in males. Biochem. Biophys. Res. Commun. 264:230-234. doi:10.1006/bbrc.1999.1494

Mylonas, C. C., I. Fakriadis, N. Papandroulakis, A. Raftopoulos, G. Iakovopoulos, M. Papadaki, and I. Sigelaki. 2017. Broodstock management and spawning induction of greater amberjack Seriola dumerili reared in tanks and sea cages in Greece. In: Aquaculture Europe 2017, Dubrovnik, Croatia, October 16-20, 2017. (Accepted oral presentation; in press.)

Mylonas, C. C., A. Fostier, and S. Zanuy. 2010. Broodstock management and hormonal manipulations of fish reproduction. Gen. Comp. Endocrinol. 165:516-534. doi:10.1016/j.ygcen.2009.03.007

Mylonas, C. C., N. Papandroulakis, A. Smboukis, M. Papadaki, and P. Divanach. 2004. Induction of spawning of cultured greater amberjack (Seriola dumerili) using GnRHa implants. Aquaculture 237:141-154. doi:10.1016/j.aquaculture.2004.04.015

Nandi, S., P. P. Banerjee, and B. R. Zirkin. 1999. Germ cell apoptosis in the testes of Sprague Dawley rats following testosterone withdrawal by ethane 1,2-dimethanesulfonate administration: Relationship to Fas? Biol. Reprod. 61:70-75. doi:10.1095/biolreprod61.1.70

Newman, A. E., D. S. Pradhan, and K. K. Soma. 2008. Dehydroepiandrosterone and corticosterone are regulated by season and acute stress in a wild songbird: Jugular versus brachial plasma. Endocrinology 149:2537-2545. doi:10.1210/en.2007-1363

Rosenfeld, H., C. C. Mylonas, C. R. Bridges, G. Heinisch, A. Corriero, R. Vassallo-Aguis, A. Medina, A. Belmonte, A. Garcia, F. de la Gándara, C. Fauvel, G. De Metrio, I. Meiri-Ashkenazi, H. Gordin, and Y. Zohar. 2012. GnRHa-mediated stimulation of the reproductive endocrine axis in captive Atlantic bluefin tuna, Thunnus thynnus. Gen. Comp. Endocrinol. 175:55-64. doi:10.1016/j.ygcen.2011.09.013

Rurangwa, E., D. E. Kime, F. Ollevier, and J. P. Nash. 2004. The measurement of sperm motility and factors affecting sperm quality in cultured fish. Aquaculture 234:1-28. doi:10.1016/j. aquaculture.2003.12.006

Schreck, C. B. 2010. Stress and fish reproduction: The roles of allostasis and hormesis. Gen. Comp. Endocrinol. 165:549-556. doi:10.1016/j.ygcen.2009.07.004

Schulz, R. W., L. R. de França, J.-J. Lareyre, F. Le Gac, H. Chiarini-Garcia, R. H. Nóbrega, and T. Miura. 2010. Spermatogenesis in fish. Gen. Comp. Endocrinol. 165:390-411. doi:10.1016/j. ygcen.2009.02.013

Schulz, R. W., and T. Miura. 2002. Spermatogenesis and its endocrine regulation. Fish Physiol. Biochem. 26:43-56. doi:10.1023/A:1023303427191

Schulz, R., and R. H. Nóbrega. 2011. The reproductive organs and processes: Regulation of spermatogenesis. In: A. P. Farrel, editor, Encyclopedia of fish physiology from genome to environment. 1st ed. Academic Press, London, UK. p. 627-634. doi:10.1016/B978-0-12-374553-8.00269-0

Scott, A. P., J. P. Sumpter, and N. Stacey. 2010. The role of the maturation-inducing steroid in male fishes: A review. J. Fish Biol. 76:183-224. doi:10.1111/j.1095-8649.2009.02483.x 
Sley, A., A. Hadj Taeib, O. Jarboui, M. Ghorbel, and A. Bouain. 2014. Reproductive biology of greater amberjack Seriola $d u-$ merili (Risso, 1810) from the Eastern Mediterranean Sea (Tunisia, Gulf of Gabes). Cah. Biol. Mar. 55:421-430.

Smith-Vaniz, W. F., F. Pina Amargos, J. Brown, M. Curtis, and J. T. Williams. 2015. Seriola dumerili. The IUCN Red List of Threatened Species. http://www.iucnredlist.org/details/198643/0. (Accessed 28 April 2017.)

Sokal, R. R., and F. J. Rohlf. 1981. Biometry: The principles and practice of statistics in biological research. Freeman WH and Company, New York, NY.

Suquet, M., R. Billard, J. Cosson, G. Dorange, L. Chauvaud, C. Mugnier, and C. Fauvel. 1994. Sperm features in turbot (Scophthalmus maximus): A comparison with other freshwater and marine fish species. Aquat. Living Resour. 7:283-294. doi:10.1051/alr:1994031

Tapanainen, J. S., J. L. Tilly, K. K. Vihko, and A. J. Hsueh. 1993. Hormonal control of apoptotic cell death in the testis: Gonadotropins and androgens as testicular cell survival factors. Mol. Endocrinol. 7:643-650.

Ulloa-Rodríguez, P., E. Figueroa, R. Díaz, M. Lee-Estevez, S. Short, and J. G. Farías. 2017. Mitochondria in teleost spermatozoa. Mitochondrion 34:49-55. doi:10.1016/j.mito.2017.01.001

Williams, G. 2012. Aromatase up-regulation, insulin and raised intracellular oestrogens in men, induce adiposity, metabolic syndrome and prostate disease, via aberrant ER- $\alpha$ and GPER signalling. Mol. Cell. Endocrinol. 351:269-278. doi:10.1016/j. mce.2011.12.017

Wilson-Leedy, J. G., and R. L. Ingermann. 2007. Development of a novel CASA system based on open source software for characterization of zebrafish sperm motility parameters. Theriogenology 67:661-672. doi:10.1016/j.theriogenology.2006.10.003
Woolveridge, I., M. de Boer-Brouwer, F. Taylor, K. J. Teerds, F. C. W. Wu, and I. D. Morris. 1999. Apoptosis in the rat spermatogenic epithelium following androgen withdrawal: Changes in apoptosis-related genes. Biol. Reprod. 60:461-470. doi:10.1095/biolreprod60.2.461

Young, K. A., and R. J. Nelson. 2001. Mediation of seasonal testicular regression by apoptosis. Reproduction 122:677-685. doi:10.1530/rep.0.1220677

Zohar, Y., and C. C. Mylonas. 2001. Endocrine manipulations of spawning in cultured fish: From hormones to genes. Aquaculture 197:99-136. doi:10.1016/S0044-8486(01)00584-1

Zupa, R., C. Fauvel, C. C. Mylonas, N. Santamaria, L. Valentini, C. Pousis, M. Papadaki, M. Suquet, F. de la Gándara, G. Bello, G. De Metrio, and A. Corriero. 2013. Comparative analysis of male germ cell proliferation in wild and captive Atlantic bluefin tuna Thunnus thynnus. J. Appl. Ichthyology 29:71-81. doi:10.1111/j.1439-0426.2012.02045.x

Zupa, R., C. Rodríguez, C. C. Mylonas, H. Rosenfeld, I. Fakriadis, M. Papadaki, J. A. Perez, C. Pousis, G. Basilone, and A. Corriero. 2017. Comparative study of reproductive development in wild and captive-reared greater amberjack Seriola dumerili (Risso,1810). PLoS One 12(1):e0169645. doi:10.1371/journal. pone. 0169645

Zupa, R., N. Santamaria, C. C. Mylonas, M. Deflorio, F. de la Gándara, R. Vassallo-Agius, C. Pousis, L. Passantino, G. Centoducati, G. Bello, and A. Corriero. 2014. Male germ cell proliferation and apoptosis during the reproductive cycle of captive-reared Atlantic bluefin tuna Thunnus thynnus (Linnaeus). Aquacult. Res. 45:1733-1736. doi:10.1111/are.12110 